\title{
Determinan Yang Mempengaruhi Kepuasan Hunian Dan "Word Of Mouth" Di Villa Ana Residence Samarinda
}

\author{
Kokom Komariah \\ FEBI IAIN Samarinda | kokom.komariah76@gmail.com
}

\begin{abstract}
Abstrak : . This study discusses the Determinan yang mempengaruhi kepuasan hunian dan "Word of Mouth" di Villa Ana Residence Samarinda. More specifically, the objectives of this study were I) to determine and analyze the effect of the product on the Company's customer satisfaction at Villa Ana Residence Samarinda, 2) To identify and analyze the effect of the price to the consumer on Villa Ana Housing Residence Samarinda, 3) To identify and analyze the influence of service developers to consumer satisfaction at Villa Ana Housing Residence Samarinda, 4) identify and analyze the effect of customer satisfaction on WOM (Word of Mouth) in Company Villa Ana Residence Samarinda. Results showed that: I) The product positive and significant effect on customer satisfaction in the Villa Ana Residence Samarinda, 2) Prices are not positive and significant effect on customer satisfaction in the Villa Ana Residence Samarinda, 3) Developer Services and significan positive effect on customer satisfaction in Villa Ana Residence Samarinda, 4) positive customer satisfaction and significantly towards WOM (Word of Mouth) in Villa Ana Residence Samarinda. The Results of this study provide practical implications that the Villa Ana Residence particularly emphasized that the indicator products in the diversity of products, product quality, design, size and Warranty. Services confidence indicator developer or Reliability, Responsiveness or Responsibility, Confidence or Assurance, Empaty and Tangible. The practical implication of this research is that it can be used as a reference by the Party Villa Ana Residence Management to improve determinants or factors affecting residential satisfaction and "Word of Mouth" at Villa Ana Residence Samarinda based on 24 indicators.
\end{abstract}

Keywords: Product, Price, Service Development, Customer Satisfaction and Word of Mouth (WOM).

\section{Pendahuluan}

Perusahaan sebagai suatu organisasi tidak lepas dari suatu masalahmasalah yang berhubungan dengan luar maupun masalah- masalah yang ada didalam perusahaan. Satu diantaranya masalah yang ada adalah dengan pelanggan (konsumen), karena pelanggan merupakan faktor penting untuk kemajuan sebuah perusahaan.

Dalam era perdagangan bebas perusahaan harus dapat mengembangkan usahanya agar mampu bertahan ditengah masing-masing persaingan perusahaan dengan segala kemampuan yang dimiliki berusaha bersaing dengan sehat, mengungguli pesaingnya demi mendapatkan pelanggan (konsumen), sehingga dapat mempertahankan kelangsungan perusahaan. Perusahaan harus mampu menghasilkan kinerja yang baik sehingga dapat member kepuasan pada pelanggannya (konsumen) misalnya dengan menawarkan produk dengan mutu berkualitas serta harga bersaing, memberikan fasilitas-fasilitas tertentu seperti memberikan pelayanan yang cepat dan memuaskan bagi konsumen. 
Salah satu yang menyebabkan bisnis bertahan dalam jangka panjang adalah kepuasan konsumen. Kepuasan konsumen adalah perbandingan antara kinerja dan harapan. Semakin tinggi kinerja yang dihantarkan perusahaan terhadap konsumen dibanding harapannya, maka akan semakin menimbulkan pengalaman yang menyenangkan bagi konsumen, dampaknya konsumen akan bersedia dengan suka rela untuk merekomendasikan pengalaman pembeliannya kepada orang lain.

Komunikasi dari mulut ke mulut (word of Mouth communication) mengacu pada pertukaran komentar, pemikiran atau ide-ide diantara dua konsumen atau lebih yang tidak satupun merupakan sumber pemasaran. Komunikasi dari mulut kemulut mempunyai pengaruh yang sangat kuat terhadap perilaku pembelian konsumen. Pengaruh komunikasi dari mulut ke mulut adalah dua kali lebih efektif dari iklan, radio, empat kali lebih efektif personal selling dan tujuh kali lebih efektif dari surat kabar atau majalah.

Salah satu strategi pemasaran yang selalu menjadi fenomena yang menarik untuk dibicarakan adalah Word of Mouth atau bisa disebut dengan promosi dari mulut ke mulut. Beberapa pemasaran mempunyai pandangan skeptic dan memandang rendah promosi semacam ini, karena sering kali promosi ini membutuhkan Opinion Leaders yang sulit ditemui. Selain itu WOM cenderung lebih sulit dikontrol. Padahal WOM bisa jadi lebih efektif dibandingkan iklan.

Kepuasan konsumen dan WOM terjadi manakala tawaran perusahan yang terdiri dari produk, harga maupun layanan mampu memenuhi harapan konsumen. Hal ini tidak mudah mengingat setiap perusahaan berusaha melakukan hal yang sama, yaitu menawarkan produk yang dapat memuaskan pelanggan sasarannya.

Persaingan yang terjadi memicu sikap perusahaan untuk terus memperhatikan kualitas produknya dan mengutamakan pelayanan yang terbaik bagi pelanggannya demi menarik perhatian calon pelanggan / konsumen maupun pelanggan tertentunya. Hal ini tercermin dari banyaknya perusahaan yang menyatakan komitmen terhadap kepuasan pelanggan dalam setiap Misi dan Visi perusahaannya.

Perusahaan perlu merumuskan strategi bauran pemasaran (marketing mix) yang tepat agar konsumen lebih tertarik untuk membeli produk yang telah dihasilkan oleh perusahaan, serta produk tersebut dapat sampai ditangan konsumen dengan cepat sehingga kebutuhan konsumen dapat tepenuhi. "Marketing mix is the set of controlloble, tactical marketing tools that the firm blends to produce the response it wants in the target market". Marketing mix meliputi item alat pemasaran, yaitu product, price, promotion, place. ${ }^{1}$

${ }^{1}$ Kotler P. dan Keller, K. L, Manajemen Pemasaran, Edisi ketiga belas jilid 1. Edisi bahasa Inggris, Person Education, inc. (Jakarta: Erlangga, 2008), 57 
Selain itu, strategi penetapan harga juga sangat penting untuk dilakukan. Harga merupakan jumlah uang yang diperlukan sebagai penukar berbagai kombinasi produk dan jasa, dengan demikian maka suatu barang haruslah dihubungkan dengan bermacam- macam barang dan/atau pelayanan, yang akhirnya akan sama dengan sesuatu yaitu produk dan jasa. Harga menggambarkan nilai yang diberikan perusahaan terhadap konsumen. Semakin tinggi nilai yang ditawarkan perusahaan dibandingkan harga yang dibayarkan maka akan semakin meningkatkan kepuasan konsumen yang akhirnya mendorong terjadi WOM.

Selain dari faktor produk, harga tersebut diatas maka faktor layanan perusahaan terhadap konsumen, merupakan faktor yang perlu mendapatkan perhatian yang serius. Pelayanan yang perlu diperhatikan adalah pelayanan yang langsung bersentuhan dengan pelanggan mulai dari awal transaksi sampai dengan setelah mereka mengkonsumsi atau telah melakukan pembelian. Jika proses layanan dari awal sampai akhir memberikan pelayanan yang menyenangkan bagi pelanggan maka akan berdampak pada kepuasan dan akhirnya mendorong terjadinya WOM.

Dari temuan penelitian - penelitian terdahulu menjelaskan bahwa terjadinya atau terciptanya WOM karena pengaruh dari mutu layanan yang menimbulkan kepuasan terhadap konsumen namun dalam hal ini perusahaan PT. Gunung Artho yang bergerak di bidang property yaitu dengan Brand Villa Ana Residence mengkaji bahwa selain kualitas pelayanan yang menimbulkan WOM tersebut ada determinan lain yang mempengaruhi kepuasan akan hunian tersebut diantaranya adalah faktor dari harga perumahan tersebut yang membuat menarik dan minat konsumen untuk memiliki hunian di Perumahan Villa Ana Residence, faktor produk, dan pelayanan perusahaan terhadap kepuasan konsumen hunian Perumahan Villa Ana Residence sehingga terciptalah WOM.

Oleh karena itu sejauh mana kepuasan dalam menimbulkan perilaku “ Word of Mouth" konsumen Villa Ana Residence menarik untuk diteliti. Dari uraian latar belakang maka peneliti tertarik untuk meneliti tentang konsumen yang sudah membeli dan menghuni Villa Ana Residence tentang judul “ Determinan yang mempengaruhi Kepuasan Hunian dan Word of Mouth di Villa Ana Residence Samarida".

Berdasarkan latar belakang masalah yang telah dikemukakan maka penelitian ini merumuskan masalah sebagai berikut:

A. Apakah produk berpengaruh langsung terhadap kepuasan hunian pada Perumahan Villa Ana Residance Samarinda?

B. Apakah harga berpengaruh langsung terhadap kepuasan hunian pada Perumahan Villa Ana Residance Samarinda? 
C. Apakah pelayanan pengembang berpengaruh langsung terhadap kepuasan hunian pada perumahan Villa Ana Residance Samarinda?

D. Apakah kepuasan hunian berpengaruh langsung terhadap WOM?

\section{Tinjauan Pustaka}

\section{a. Pengertian Manajemen Pemasaran}

Manajemen pemasaran merupakan satu diantara dari bagian ilmu manajemen yang lebih spesifik membahas masalah dan mekanisme pemasaran. Manajemen pemasaran merupakan suatu sistem atau tata cara bagaimana pemasaran dapat dilakukan dengan baik, terencana serta terperinci, sehingga sasaran dari suatu kegiatan penyaluran produk mulai dari produsen hingga ke tangan konsumen dapat terlaksana secara baik dan tujuan pencapaian memperoleh profit perusahaan sesuai dengan yang direncanakan.

Menurut Assauri bahwa Manajemen Pemasaran merupakan kegiatan menganalisa perencanaan, pelaksanaan dan pengendalian program-program yang dibuat untuk membentuk, membangun, dan memelihara. ${ }^{2}$ Keuntungan dari pertukaran melalui sasaran pasar guna mencapai tujuan organisasi (perusahaan) dalam jangka panjang.

\section{b. Pengertian Pemasaran}

Ada beberapa definisi mengenai pemasaran diantaranya adalah :

1. Menurut Kotler (marketing) Pemasaran adalah kegiatan manusia yang diarahkan untuk memenuhi kebutuhan dan keinginan melalui proses pertukaran. ${ }^{3}$

2. Menurut Achmadi mengemukakan pendapat dari Smith dari buku "Great Answers to Tought Marketing" yaitu "Pengertian Pemasaran adalah proses manajemen yang bertanggung jawab untuk mengidentifikasikan, mengantisipasikan dan memuaskan kebutuhan pelanggan yang menguntungkan"

Pengertian menurut Kotler dan Keller ${ }^{4}$ Pemasaran adalah sebagai suatu proses social dan managerial yang membuat individu dan kelompok memperoleh apa yang mereka butuhkan dan keinginan lewat penciptaan dan pertukaran timbal balik produk dan nilai dengan orang lain. Kotler menekankan kebebasan dalam menawarkan produk maupun jasa serta kebebasan untuk melakukan pertukaran baik terhadap individu maupun kelompok.

\footnotetext{
${ }^{2}$ Assauri Sofjan, Manajemen Pemasaran, (Jakarta: Rajawali Pers, 2003), 12

${ }^{3}$ Kotler P. dan Keller, K. L, Manajemen..., 8
} 


\section{c. Model - Model Perilaku Konsumen}

Adapun pengertian daripada perilaku konsumen menurut Kotler ${ }^{5}$ bahwa perilaku konsumen adalah studi tentang bagaimana individu, kelompok, dan organisasi memilih, membeli, menggunakan, dan bagaimana barang, jasa, ide, atau pengalaman untuk memuaskan kebutuhan dan keinginan mereka. berikut :

yang mempengaruhi persepsi dan ekspektasi pelanggan, yaitu sebagai

1. Apa yang didengar pelanggan dari pelanggan lainnya (Worth of Mouth Communication). Dimana hal ini merupakan faktor potensial yang menentukan ekspektasi pelanggan sebagai contoh, seorang pelanggan memiliki perusahaan yang diharapkan dapat memberikan pelayanan dengan kualitas tinggi berdasarkan rekomendasi teman - teman atau tetangganya.

2. Ekspektasi pelanggan sangat tergantung dari karakteristik individu dimana kebutuhan pribadi (personal needs).

3. Pengalaman masa lalu (past experience) dalam menggunakan pelayanan dapat juga mempengaruhi tingkat ekspetasi pelanggan.

4. Komunikasi dengan pihak eksternal (external communication) dari memberi layanan memberikan peranan kunci dalam membentuk ekspetasi pelanggan. Berdasarkan external communication perusahaan pemberi layanan dapat memberikan pesan - pesan secara langsung maupun tidak langsung kepada pelanggannya. Sebagai contoh dari pengaruh adanya external communication adalah harga dimana biaya pelayanan sangat berperan penting dalam membentuk ekspetasi pelanggan.

\section{d. Pengertian WoM}

Word of Mouth atau sering disingkat WoM, menurut Word of Mouth marketing Association (WOMMA), merupakan usaha meneruskan informasi dari satu konsumen ke konsumen lain. Sedangkan Word of Mouth marketing menurut WoMma adalah memberikan pelanggan alasan untuk membicarakan produk dan layanan anda, dan memudahkan pembicaraan tersebut terjadi. Word of Mouth marketing adalah seni dan ilmu membangun komunikasi yang baik dan saling menguntungkan dari konsumen maupun konsumen ke produsen.

Fenomena Word of Mouth diyakini bisa mendorong pembelian oleh konsumen, bisa mempengaruhi komunitas, efisien karena tidak memerlukan budget yang besar (low cost). Komunikasi Word of Mouth bukan merupakan faktor dominan dalam berbagai situasi. Komunikasi Word of Mouth tidak mungkin merubah perilaku seseorang jika memiliki loyalitas merek yang kuat. 
Word of Mouth tidak mungkin merubah perilaku seseorang ketika konsumen tersebut ragu - ragu terhadap suatu produk, karena informasi negative yang dapat dipercaya. Word of Mouth bukanlah faktor dominan untuk tiap kategori produk. Word of Mouth sebagian besar penting untuk kelompok referensi, mungkin dapat menjadi sumber informasi dan suatu pengaruh.

Berkaitan dengan komunikasi yang ada pada suatu organisasi, menurut Hoskins (2007) dilihat dari sifatnya salah satunya adalah komunikasi Word of Mouth Communication atau komunikasi mulut ke mulut. 6 Menurutnya, komunikasi ini dibutuhkan untuk kepentingan internal dan eksternal organisasi.

\section{e. $\quad$ Kinerja Word of Mouth}

Secara bebas, kinerja WoM dapat diartikan sebagai kesediaan konsumen menyebarkan rekomendasinya kepada calon konsumen lain secara gratis.

Produsen berharap bahwa kepuasan pelanggan yang dapat membantu pelanggan menciptakan perilaku pelanggan yang dapat membantu perusahaan menciptakan komunikasi yang lebih efektif. Sebagai contoh, kepuasan konsumen akan membentuk WoM yang positif bagi perusahaan. ${ }^{7}$ Hal ini dapat menguranngi biaya pemasaran untuk menarik konsumen baru dapat ditekan dengan semakin tingginya kepuasan.

Komunikasi WOM yang positif telah diakui sebagai wahana yang berharga untuk mempromosikan prosuk dan jasa dari sebuah perusahaan. Sebenarnya dengan sifat yang nonkomersial, komunikasi WOM dipandang tidak terlalu spektis dari upaya-upaya yang dilakukan oleh perusahaan, walaupun komunikasi WOM bisa menjadi faktor yang sangat mempengaruhi setiap keputusan pembelian. Riset sebelumnya menunjukkan bahwa komunikasi WOM ini sangat penting untuk bidang jasa.

\section{f. Kepuasan Konsumen terhadap Worth of mouth (WOM)}

Kepuasan konsumen atau pelanggan merupakan hal yang penting bagi penyedia jasa, karena pelanggan akan menyebarluaskan rasa puasnya ke calon pelanggan, sehingga akan menaikkan reputasi perusahaan tersebut, jdi apabila pelanggan merasa puas, maka ia akan menciptakan WOM kepada rekan maupun keluarganya.

Kepuasan konsumen atau pelangga dapat mempengaruhi hasil kinerja, termasuk loyalitas dan komunikasi WOM atau minat mereferensikan.

${ }^{6}$ Jim Hoskins, Word of Mouth Research: Principals and Application, The journal Advertising Research. ARF, 2007.

7 Xiening Luo \& Hamburg, Christian, Neglected outcomes of cutomer satisfaction. Journal of Marketing. 2007. 
Kepuasam atau ketidakpuasan konsumen adalah respon konsumen terhadap evaluasi ketidaksesuaian yang dirasakan antara harapan sebelunya (norma kinerja lainnya) dan kinerja actual produk yang dirasakan setelah pemakainnya. Terciptanya kepuasan konsumen dapat memberikan manfaat, diantaranya membentuk rekomendasi dari mulut ke mulut (word of mouth). Konsumen yang merasa puas bahkan sangat puas atau sangat senang (delighted customer) cenderung akan menjadi duta atau rasul bagi perusahaan (Apostles of a firm), konsumen akan membeli hanya dari satu pemasok dan menyebbarkan berita yang baik tentang produk dan perusahaan. Selain itu, Lovelock dan Wright menyatakan bahwa konsumen yang sangat puas akan menyebarkan cerita positif dari mulut ke mulut dan bahkan akan menjadi iklan berjalan dan akan berbicara bagi suatu perusahaan. ${ }^{8}$

\section{Metode Penelitian}

Penelitian ini dirancang untuk mengetahui variable yang mempengaruhi terhadap kepuasan hunian dan "Word of Mouth" di Villa Ana Residence Samarinda pada PT Gunung Artho. Sedangkan objek yang akan diteliti adalah individu yang telah membeli perumahan di Villa Ana Residence Samarinda.

\section{a. Variabel Penelitian dan Definisi Operasional}

Variabel penelitian ini adalah sesuatu hal yang berbentuk apa saja yang ditetapkan oleh penelitian untuk dipelajari sehingga dapat diperoleh informasi tentang hal tersebut, kemudian ditarik kesimpulannya. ${ }^{9}$

Variabel-variabel dalam penelitian ini adalah:

Variabel bebas ( independent variable ) adalah variabel yang mempengaruhi atau yang menjadi sebab perubahannya atau timbulnya variabel terikat ( dependent variable ). ${ }^{10}$ Dalam penelitian ini yang menjadi variabel bebas adalah faktor produk (X1), harga (X2), pelayanan pengembang (X3).

Variabel terikat ( Dependent variable) merupakan variabel yang mempengaruhi atau yang menjadi akibat, karena adanya variabel bebas. ${ }^{11}$ Dalam penelitian ini yang menjadi variabel terikat adalah kepuasan hunian (Y1), dan Word of Mouth (WOM) (Y2).

8 Christopher Lovelock and Jochen Wirtz, Service Marketing people Technology strategy. Sixty Edition, (Singapore: Prentree Hall 2008), 105

${ }^{9}$ Sugiyono, Metode Penelitian Bisnis, (Bandung: Penerbit Alfabeta, 2008), 59

${ }^{10}$ Sugiyono, Metode Penelitian..., 59

${ }^{11}$ Sugiyono, Metode Penelitian..., 59 


\section{b. Jenis data menurut Sumber}

Adapun sumber data digunakan dalam penelitian ini adalah :

Data Primer yaitu Data yang diperoleh secara langsung dari sumber dari sumbernya dimana dicatat untuk pertama kalinya dan masih perlu diolah lebih lanjut agar bisa memberikan hasil bagi penelitian. Data primer digunakan dalam penelitian ini diperoleh melalui penyebaran kuesioner kepada responden yang telah sesuai dengan kriteria yang ditetapkan yaitu tentang penilaian / persepsi konsumen terhadap faktor harga, faktor produk, faktor kualitas pelayanan, faktor kepuasan konsumen dan WoM selama menjadi penghuni Perumahan Villa Ana Residence Samarinda.

Data Sekunder adalah data yang sudah lebih dahulu disampaikan dan dilaporkan orang lain diluar penelitian. Data sekunder bisa diperoleh melalui studi dokumentasi dengan mempelajari berbagai tulisan melalui buku, jurnal, majalah, dan sumber - sumber lainnya yang mendukung penelitian ini.

\section{c. Populasi Penelitian}

Menurut Sugiyono populasi merupakan wilayah generalisasi yang terdiri atas objek atau subjek yang mempunyai kualitas dan karakteristik tertentu. ${ }^{12}$ Populasi penelitian ini adalah konsumen yang menghuni di Villa Ana Residence Samarinda.

Populasi dalam penelitian ini adalah seluruh pelanggan atau konsumen yang membeli dan menghuni di Villa Ana Residence Samarinda yang berjumlah 100 konsumen namun diambil 75 konsumen sebagai sampel.

\section{d. Model Analisis Data}

Analisis yang digunakan adalah PATH analisis atau disebut dengan analisis jalur karena antara variabel produk, harga, pelayanan pengembang,sebagai intervening kepuasan konsumen dan kepuasan konsumen sebagai intervening terhadap WOM. " Analisis jalur adalah suatu teknik untuk menganalisis hubungan sebab akibat yang terjadi pada regresi berganda jika variabel bebasnya mempengaruhi variabel tergantung tidak hanya secara langasung tetapi juga secara tidak langsung"

Analisis jalur adalah suatu teknik pengembangan dari regresi linier ganda. Teknik ini digunakan untuk menguji besarnya sumbangan (kontribusi) yang ditunjukkan oleh koefisien jalur pada setiap diagram jalur dari hubungan kausal antar variabel $\mathrm{X}_{1}, \mathrm{X}_{2}$ dan $\mathrm{X}_{3}$ terhadap $\mathrm{Y}$.

${ }^{12}$ Sugiyono, Metode Penelitian..., 60 


\section{Hasil Penelitian Dan Pembahasan}

\section{Gambaran Umum Perusahaan}

PT. Gunung Artho adalah Perusahaan Swasta Nasional yang didirikan pada tahun 2010 berdasarkan Akta No. 35 tanggal 07 Oktober 2010 dibuat dihadapan Achmad Dahlan, SH Notaris di Samarinda dan telah mendapatkan pengesahan dari Menteri Kehakiman dan Hak Asasi Manusia Republik Indonesia No. C-83. HT 0301 Th. 1992 yang bergerak dalam Bidang Jasa Developer Property dan Kontraktor.

Saat ini PT. Gunung Artho selaku Developer Property dan Kontraktor Perumahan Villa Ana telah mendirikan Perumahan dengan beberapa type, antara lain:

1. Type $36 / 98$

2. Type $45 / 98$

3. Type $54 / 112$

4. Type $54 / 128$

5. Type $80 / 120$

Analisis data yang digunakan adalah statistik deskriptif untuk mengembangkan indikasi jawaban responden dari berbagai kontruk yang dikembangkan serta statistic diferensial untuk menguji hipotesisinya, dengan menggunakan analisis dalam model regresi linier khususnya menggunakan analisis path.

\section{Pretest}

Data pretest yang diperoleh dari penyebaran 75 kuesioner tersebut adalah dengan menggunakan software SPSS 17 for Windows. Hasil output yang diperoleh akan digunakan untuk memgevaluasi isi kuesioner penelitian, yang pada langkah selanjutnya mengevaluasi isi kuesioner penelitian, yang pada langkah selanjutnya akan disebarkan kembali untuk diisi oleh responden lainnya.

\section{Uji Validitas}

Uji validitas dilakukn untuk menilai seberapa baik suatu instrument ataupun proses pengukuran terhadap konsep yang diharapkan untuk mengetahui apakah yang kita tanyakan dalam kuesioner sudah sesuai dengan konsepnya. ${ }^{13}$

Suatu kuesioner dapat dikatakan valid jika pertanyaan pada kuesioner mampu untuk mengungkapkan sesuatu yang akan diukur oleh kuesioner tersebut. Suatu skala pengukuran disebut valid jika melakukan apa yang seharusnya di ukur. Bila skala pengukuran tidak valid maka tidak bermanfaat

${ }^{13}$ Imam Ghozali, Aplikasi analisis Multivariate dengan program SPSS Edisi II. BPFE (Semarang: Universitas Diponogoro, 2004), 45 
bagi pene liti karena tidak mengukur atau melakukan apa yang seharusnya dilakukan.

Uji Validitas adalah esensi kebenaran penelitian. Sebuah instrument dikatakan valid apabila mampu, mengukur apa yang hendak diukur serta dapat mengungkapkan data dan variabel yang akan diteliti secara tepat.

Pengujian instrument dari 24 (dua puluh empat) menghasilkan $\mathrm{r}$ hitung $>\mathrm{r}$ tabel berdasarkan pengujian terhadap 75 (tujuh puluh lima) responden. Dapat dilihat pada Tabel:

Tabel Item-Total Statistics

\begin{tabular}{|l|l|l|l|l|}
\hline & $\begin{array}{l}\text { Scale } \\
\text { mean of } \\
\text { item } \\
\text { deleted }\end{array}$ & $\begin{array}{l}\text { Scale } \\
\text { Variance } \\
\text { of item } \\
\text { deleted }\end{array}$ & $\begin{array}{l}\text { Corrected } \\
\text { item - total } \\
\text { correlation }\end{array}$ & $\begin{array}{l}\text { Cronbach's } \\
\text { Alpha of } \\
\text { item } \\
\text { Deleted }\end{array}$ \\
\hline No1 & 14.60 & 9.486 & .698 & .853 \\
\hline No2 & 14.63 & 8.913 & .741 & .840 \\
\hline No3 & 14,68 & 8.707 & .617 & .870 \\
\hline No4 & 14.64 & 8.558 & .762 & .834 \\
\hline No5 & 15.05 & 7.511 & .753 & .839 \\
\hline No6 & 14.57 & 9.843 & .814 & .880 \\
\hline No7 & 14.57 & 10.248 & .806 & .884 \\
\hline No8 & 14.65 & 10.284 & .694 & .904 \\
\hline No9 & 14.43 & 9.761 & .755 & .892 \\
\hline No10 & 14.41 & 8.786 & .808 & .883 \\
\hline No11 & 14.28 & 7.448 & .757 & .859 \\
\hline No12 & 14.47 & 6.874 & .741 & .864 \\
\hline No13 & 14.43 & 7.221 & .782 & .852 \\
\hline No14 & 14.31 & 7.351 & .803 & .849 \\
\hline No15 & 14.20 & 8.243 & .582 & .895 \\
\hline No16 & 14.95 & 8.997 & .820 & .876 \\
\hline No17 & 15.12 & 8.404 & .729 & .901 \\
\hline No18 & 15.05 & 8.565 & .813 & .877 \\
\hline No19 & 14.75 & 9.813 & .763 & .891 \\
\hline No20 & 14.96 & 9.417 & .754 & .890 \\
\hline No21 & 10.92 & 5.318 & .802 & .905 \\
\hline No22 & 11.08 & 4.507 & .829 & .899 \\
\hline No23 & 10.93 & 5.144 & .834 & .894 \\
\hline N05 & 10.87 & 4.874 & .831 & .894 \\
\hline Sumber & & & & \\
\hline & & & \\
\hline
\end{tabular}

Sumber : Output SPSS 


\section{Uji Reliabiitas}

Adapun cara yang digunakan untuk menguji realibilitas kuesioner dalam penelitian ini adalah mengukur realibilitas dengan uji statistic Cronbach alpha. Untuk mengetahui kuesioner tersebut sudah reliabel akan dilakukan pengujian realibilitas kuesioner dengan bantuan komputer program SPSS. Kriteria penilaian uji reliabilitas adalah:

1. Apabila hasil koefisien Alpha lebih besar dari taraf signifikan $60 \%$ atau 0,6 maka kuesioner tersebut reliabel.

2. Apabila hasil koefisien Alpha lebih kecil dari taraf signifikan $60 \%$ atau 0,6 maka kuesioner tersebut tidak reliabel.

\section{Uji Reliabilitas Variabel Produk}

Uji Reliabilitas kuesioner ini dilakukan dengan tujuan untuk mengetahui konsistensi derajat ketergantungan dan stabilitas dari variabel produk. Setelah dilakukan, didapat koefisien alpha sebagai berikut :

\begin{tabular}{|l|l|l|}
\hline Cronbach's Alpha & $\mathrm{N}-$ of item & Keterangan \\
\hline 0,874 & 5 & Reliabel \\
\hline
\end{tabular}

\section{Tabel Reliability Statistic - Variabel Produk}

Sumber : Output SPSS

Tabel diatas menunjukkan nilai Cronbach's Alpha dari lima item untuk variabel produk sebesar 0,874 yang berarti memenuhi persyaratan yaitu diatas 0,6 . Dengan demikian, dapat disimpulkan bahwa item dalam kuesioner dianggap telah reliabel, konsisten dan relevan terhadap variabel produk dan layak untuk diteliti lebih lanjut.

\section{Uji Reliabilitas Variabel Harga}

Setelah dilakukan pengujian, didapat koefisien alpha sebagai berikut :

Tabel Reliability Statistic - Variabel Harga

\begin{tabular}{|l|l|l|}
\hline Cronbach's Alpha & $\mathrm{N}-$ of item & Keterangan \\
\hline 0,909 & 5 & Reliabel \\
\hline
\end{tabular}

Sumber : Output SPSS

Tabel diatas menunjukkan nilai Cronbach's Alpha dari lima item untuk variabel harga sebesar 0,909 yang berarti memenuhi persyaratan yaitu diatas 0,6. Dengan demikian, dapat disimpulkan bahwa item dalam kuesioner dianggap telah reliabel, konsisten dan relevan terhadap variabel harga dan layak untuk diteliti lebih lanjut. 


\section{Uji Reliabilitas Variabel Pelayanan Pengembang}

Setelah dilakukan pengujian, didapat koefisien alpha sebagai berikut :

\begin{tabular}{|l|l|l|}
\hline Cronbach's Alpha & $\mathrm{N}-$ of item & Keterangan \\
\hline 0,889 & 5 & Reliabel \\
\hline
\end{tabular}

\section{Tabel Reliability Statistic - Variabel Pelayanan Pengembang} Sumber : Output SPSS

Tabel diatas menunjukkan nilai Cronbach's Alpha dari lima item untuk variabel pelayanan pengembang sebesar 0,889 yang berarti memenuhi persyaratan yaitu diatas 0,6 . Dengan demikian, dapat disimpulkan bahwa item dalam kuesioner dianggap telah reliabel, konsisten dan relevan terhadap variabel pelayanan pengembang dan layak untuk diteliti lebih lanjut.

\section{Uji Reliabilitas Variabel Kepuasan Konsumen}

Setelah dilakukan pengujian, didapat koefisien alpha sebagai berikut :

\begin{tabular}{|l|l|l|}
\hline Cronbach's Alpha & $\mathrm{N}$ - of item & Keterangan \\
\hline 0,907 & 5 & Reliabel \\
\hline
\end{tabular}

Tabel Reliability Statistic - Variabel Kepuasan Konsumen

Sumber : Output SPSS

Tabel diatas menunjukkan nilai Cronbach's Alpha dari lima item untuk variabel kepuasan konsumen sebesar 0,907 yang berarti memenuhi persyaratan yaitu diatas 0,6. Dengan demikian, dapat disimpulkan bahwa item dalam kuesioner dianggap telah reliabel, konsisten dan relevan terhadap variabel kepuasan konsumen dan layak untuk diteliti lebih lanjut.

\section{Uji Reliabilitas Variabel WOM}

Setelah dilakukan pengujian, didapat koefisien alpha sebagai berikut :

Tabel Reliability Statistic - Variabel WOM

\begin{tabular}{|l|l|l|}
\hline Cronbach's Alpha & $\mathrm{N}-$ of item & Keterangan \\
\hline 0,922 & 4 & Reliabel \\
\hline
\end{tabular}

Sumber : Output SPSS

Tabel diatas menunjukkan nilai Cronbach's Alpha dari empat item untuk variabel WOM sebesar 0,922 yang berarti memenuhi persyaratan yaitu diatas 0,6. Dengan demikian, dapat disimpulkan bahwa item dalam kuesioner dianggap telah reliabel, konsisten dan relevan terhadap variabel WOM dan layak untuk diteliti lebih lanjut.

\section{Uji Asumsi Klasik}

Sebelumnya dilakukan Uji Regresi, terlebih dahulu akan dilakukan Uji Asumsi Klasik. Model regresi linier berganda (Multiple Linier Regresi Tan) 
dapat disebut sebagai model yang baik jika model tersebut memenuhi beberapa asumsi yang kemudian disebut dengan asumsi klasik. Sehingga disini akan dilihat terlebih dahulu apakah model didalam penelitian ini sudah baik dan dapat dilakukan pengujian hipotesis.

\section{Uji Normalitas Data}

Uji Normalitas bertujuan untuk menguji apakah model regresi variabel dependen dan variabel independen keduanya memiliki distribusi normal. Model regresi yang baik adalah memiliki distribusi data normal atau mendeteksi normal.

Uji normalitas bertujuan untuk menguji apakah dalam model regresi, variabel terikat dan variabel bebas keduanya mempunyai distribusi data normal atau mendekati normal.

Tabel Tabel Uji Normalitas berupa Grafik.

Normal P-P Plot of Regression Standardized Residual

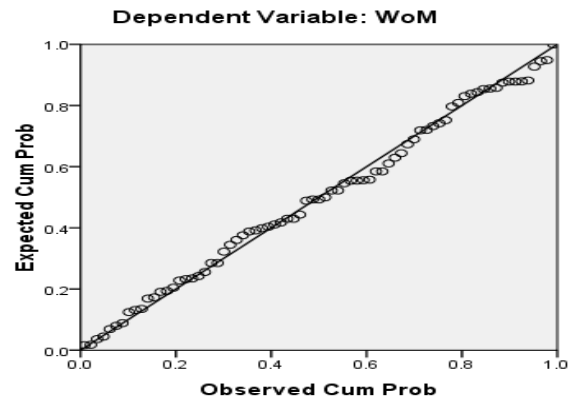

Hasil Uji Normalitas dapat dideteksi dengan melihat penyebaran data (titik) pada sumbu diagonal dari grafik. Jika data (titik) menyebar disekitar garis diagonal dan mengikuti arah garis diagonal, maka menunjukkan pola distribusi normal yang mengindikasikan bahwa model regresi memenuhi asumsi normalitas. Dan hasil penelitian diatas menunjukkan bahwa model regresi memenuhi asumsi normalitas.

\section{Uji Multikolinearitas}

Salah satu asumsi yang mendasari model adalah tidak adanya satu hubungan linier yang sempurna antara beberapa atau semua variabel independen. Hal ini model tidak melanggar asumsi tidak ada multikolinieritas. Pedoman suatu model regresi yang bebas multikolinieritas adalah mempunyai nilai Variance Inflation Factor (VIF) disekitar angka 1 (satu) dan mempunyai angka tolerance mendekati angka 1 (satu). HasilUji Multikolinearitas pada 
penelitian ini dapat dilihat pada tabel berikut 4.17 dimana nilai VIF disekitar angka 1 (satu) dan mempunyai angka tolerance angka 1 (satu) sehingga dapat disimpulkan data yang ada tidak mengandung multikolineritas.

Dari hasil penelitian menunjukkan bahwa nilai Toleranse $\geq 0,10$ atau sama dengan Nilai VIF $\leq$. Maka dari hasil diatas setiap variabel menunjukkan tingkat kolinearitas yang masih dapat ditolelir. Dari tabel tersebut menunjukkan nilai toleransi Variance Inflantion Factor (VIF) dari ke empat variabel bebas. Nilai toleransi dari variabel produk, variabel harga, variabel layanan dan kepuasan konsumen berturut-turut adalah 4,102, 3,171, 2,767dan 1,000. Hal ini menunjukkan keempat variabel tersebut memenuhi persyaratan kurang dari 10. Dengan demikian, dapat disimpulkan bahwa tidak terjadi multikolinearitas atau korelasi antara satu variabel dengan variabel bebas lainnya. Sehingga dapat dianalisis dengan menggunakan model regresi linier.

\section{Uji Autokorelasi}

Tujuan dari pengujian ini adalah untuk mengetahui apakah dalam sebuah model ada korelasi antara kesalahan pengganggu pada periode $t$ dengan kesalahan pada periode $\mathrm{t}-1$ (sebelumnya). Jika terjadi, maka model terdapat problem autokorelasi. Model tidak melanggar asumsi tidak ada autokorelasi. Untuk mendeteksi adanya autokorelasi dalam model, dapat dilihat dari besaran Durbin Waston, dengan ketentuan sebagai berikut:

Berdasarkan hasil perhitungan nilai Durbin Wistonnya sebesar 1,764 dan 1,899 berada pada range 1,55 - 2,46 yang berarti tidak ada autokorelasi, sehingga dapat disimpulkan data yang ada tidak mengandung autokorelasi.

\section{Uji Heteroskedasdisitas}

Uji Heteroskedasdisitas digunakan untuk menguji apakahdalam metode regresi linier kesalahan pengganggu (e) memiliki varians yang sama atau tidak dari pengamatan yang lain. Model regresi yang memenuhi persyaratan yaitu terdapat kesamaan varians dari residual satu ke residual pengamatan yang lain tetap atau disebut homoskedestisitas. Model regresi yang baik adalah homoskedastisitas atau tidak terjadi heteroskedastisitas.

Salah satu cara mendeteksi ada tidaknya heteroskedastisitas dalam penelitian ini adalah menggunakan atau melihat pada grafik antara nilai prediksi variabel terikat (dependen) yaitu Zpred deng residual SRESID, dimana sumbu y adalah y yang telah diprediksi dan sumbu $\mathrm{x}$ adalah residual (y prediksi - y sesungguhnya) yang telah di studentized. Hasilnya dapat dilihat pada grafik dibawah ini. 


\section{Tabel Grafik Heteroskedastisitas}

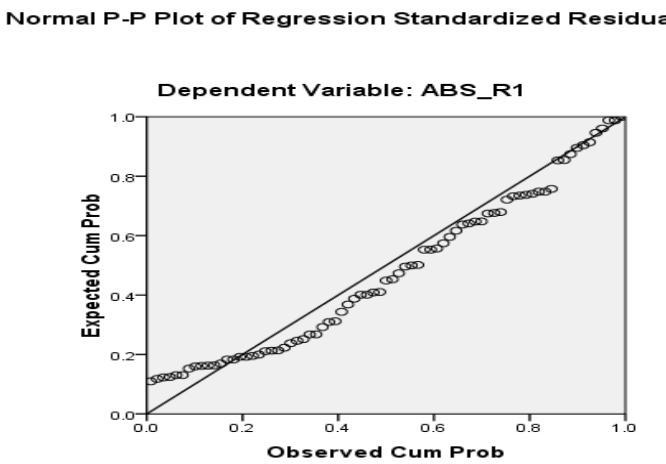

\section{Kesimpulan Uji Asumsi Klasik}

Hasil Uji Asumsi Klasik yang telah dilakukan yaitu normalitas, linearitas, autokorelasi, heteroskedastisitas dan multikolenieritas. Variabel produk, variabel harga, variabel pelayanan pengembang, variabel kepuasan konsumen memiliki distribusi yang tidak normal sehingga perlu dilakukan data recoring dengan dummy variabel. Variabel experiential marketing tidak memiliki masalah normalitas namun terdapat heteroskadastisitas sehingga dilakukan data recording untuk menjadikan dummy variabel. Variabel dependen yaitu Word of mouth tidak memiliki masalah baik normalitas maupu heteroskedastisitas. Untuk menguji multikolenieritas, keseluruhan variabel tersebut tidak ada yang memiliki masalah dengan multikolineariaritas, setelah melakukan uji asumsi klask, seluruh variabel telah siap untuk dilakukan pengujian hipotesis.

\section{Uji Hipotesis}

Dalam menentukan pengaruh dari variabel independen (Produk, harga dan Pelayanan pengembang) terhadap kepuasan konsumen dan dari variabel dependen kepuasan konsumen terhadap word of mouth, penelitian ini akan menggunakan uji regresi linear berganda. Digunakannya uji regresi linier berganda karena model dalam penelitian ini memiliki lebih dari satu variabel independen.

\section{Uji F (Simultan)}

Uji F dilakukan untuk mengetahui pengaruh variabel - variabel independen dengan variabel dependen secara simultan. Dapat juga dikatakan, pengujian ini dilakukan untuk mengetahui apakah model yang ada dalam penelitian dapat memenuhi variabel dependen secara signifikan 
Tabel Anova (a)

\begin{tabular}{|c|c|c|c|c|c|c|}
\hline \multicolumn{2}{|c|}{ Model } & $\begin{array}{c}\text { Sum of } \\
\text { Square }\end{array}$ & df & $\begin{array}{c}\text { Mean } \\
\text { Square }\end{array}$ & F & Sig \\
\hline \multirow{2}{*}{1} & Regression & 30,313 & 3 & 10,104 & 68,004 & $0.000^{\mathrm{b}}$ \\
\cline { 2 - 7 } & Residual & 10,5449 & 71 & .149 & & \\
\cline { 2 - 8 } & Total & 40,862 & 74 & & & \\
\hline
\end{tabular}

a. Predictors (Constant), X3, X2, X1

b. $\quad$ Dependent variabel $=\mathrm{Y} 1$

Sumber : Output SPSS

Tabel Anova (b)

\begin{tabular}{|l|l|l|l|l|l|l|}
\hline \multicolumn{2}{|c|}{ Model } & $\begin{array}{l}\text { Sum of } \\
\text { Square }\end{array}$ & Df & $\begin{array}{l}\text { Mean } \\
\text { Square }\end{array}$ & F & Sig- \\
\hline \multirow{3}{*}{} & Regression & 30,772 & 1 & 30,772 & 250,216 & $0,000^{\mathrm{b}}$ \\
\cline { 2 - 7 } & Residual & 8,978 & 73 & .123 & & \\
\cline { 2 - 7 } & Total & 39,750 & 74 & & & \\
\hline
\end{tabular}

a. $\quad$ Predictors (Constant), $\mathrm{Y} 1$

b. $\quad$ Dependent variabel $=\mathrm{Y} 2$

Sumber : Output SPSS

Untuk menguji pengaruh ketiga variabel bebas terhadap variabel terikat secara bersama-sama atau simultan, dapat dilakukan dengan Uji F. tabel diatas menunjukkan nilai F hitung untuk variabel produk, harga, pelayanan pengembang sebesar dan 68,004 dengan tingkat signifikansi 0,000 karena tingkat signifikasi kurang dari 0,05 dan F hitung lebih besar dari F tabel maka dapat dinyatakan bahwa model regresi dapat digunakan untuk memprediksi variabel produk, harga. Pelayanan pengembang, secara simultan mempunyai penggaruh terhadap kepuasan konsumen. Dan F hitung untuk variabel kepuasan konsumen sebesar 250,216 dengan tingkat signifikan sebesar 0,000 karena tingkat signifikan kurang dari 0,05 dan F hitung lebih besar dari F tabel maka dinyatakan bahwa kepuasan konsumen mempunyai pengaruh simultan terhadap WOM (Word Of Mouth).

\section{Uji t-test (Parsial)}

Pengujian uji-t adalah dilakukan untuk mengetahui pengaruh secara parsial dari masing-masing variabel independent yang digunakan berkaitan dengan kepuasan konsumen dan kepuasan konsumen terhadap WOM . Pengujian hipotesis dilakukan dengan menggunakan uji-t yang dipakai untuk melihat tingkat signifikasi dari pengaruh variabel exogenous secara indivi terhadap variabel exogenous dengan menganggap bahwa variabel lain bersifat konstan. Uji ini dilakukan dengan membandingkan thitung dengan tabel. 
Uji t-statistik dilakukan untuk menyelidiki lebih lanjut diantara variabel independen produk, harga, pelayanan pengembang. Variabel manakah yang mempengaruhi atau berpengaruh signifikan terhadap kepuasan konsumen dan WOM (Word Of Mouth). Hasil Uji t-statistik adalah sebagai berikut :

Untuk menguji pengaruh masing-masing variabel bebas terhadap variabel terikat secara satu per satu atau parsial dapat dilakukan dengan uji t. tabel diatas menunjukkan nilai thitung dapat dilihat pada tabel 4.9 untuk variabel kepuasan konsumen adalah sebesar 15,818 dengan tingkat signifikan sebesar 0,000. T hitung yang bernilai 15,818 tersebut memiliki milai yang lebih besar dari t tabel. Sedangkan tingkat signifikasi memiliki nilai yang lebih kecil dari alpha $(0,6)$. Dengan demikian, dapat disimpulkan bahwa kepuasan konsumen memiliki pengaruh yang signifikasi terhadap WOM (Word Of Mouth).

Nilai $\mathrm{t}$ hitungdapat dilihat pada tabel 4.8 untuk variabel produk sebesar 2,694 dengan tingkat signifikasi 0,009. T hitung yang bernilai 2,694 tersebut memiliki nilai yang lebih besar dari t tabel. Sedangkan tingkat signifikasi memiliki nilai lebih kecil dari $(0,6)$. Dengan demikian dapat disimpulkan bahwa variabel produk memiliki pengaruh yang signifikasi terhadap kepasan konsumen.

Nilai $\mathrm{t}$ hitung untuk variabel harga sebesar 1,247 dengan tingkat signifikasi 0,217 . T hitung yang bernilai 1,247 tersebut memiliki nilai yang lebih besar dari t tabel. Sedangkan tingkat signifikasi memiliki nilai lebih kecil dari alpha $(0,6)$. Dengan demikian dapat disimpulkan bahwa variabel harga tidak memiliki pengaruh yang signifikasi terhadap kepuasan konsumen.

Nilai $\mathrm{t}$ hitung untuk variabel produk sebesar 4,613 dengan tingkat signifikasi 0,000 . T hitung yang bernilai 4,613 tersebut memiliki nilai yang lebih besar dari $t$ tabel. Sedangkan tingkat signifikasi memiliki nilai lebih kecil dari alpha $(0,6)$. Dengan demikian dapat disimpulkan bahwa variabel layanan pengembang memiliki pengaruh yang signifikasi terhadap kepuasan konsumen.

\section{Uji Analisis Path}

Uji Analisis Path atau lebih dikenal dengan teknik analisis jalur sebenarnya merupakan perkembangan korelasi yang diuraikan menjadi beberapa interprestasi akibat yang ditimbulkannya.

Bagian ini menguraikan tiap-tiap jalur dalam model dengan menggunakan analisis jalur. Tiap-tiap jalur yang diuji menunjukkan adanya pengaruh langsung maupun tidak langsung Produk, Harga, Pelayanan Pengembang terhadap Kepuasan Konsumen dan Kepuasan Konsumen terhadap WOM (Word of Mouth). Sebelum menguji ada tidaknya pengaruh langsung maupun tidak langsung tersebut, masing-masing jalur di uji signifikasi terlebih dahulu. Apabila terdapat jalur yang tidak signifikan maja diberlakukan Triming Theory yaitu dengan menghilangkan atau menghapus jalur yang tidak 
signifikan. Kemudian dari hasil struktur yang baru tersebut dihitung kembali masing-masing koefisien jalurnya (Path Coefficient). Dengan mengetahui signifikan tiap-tiap jalur tersebut akan mejawab apakah hipotesis yang diajukan diterima atau ditolak. Masing-masing jalur yang diuji mewakili hipotesis yang ada dalam penelitian ini.

Berdasarkan hasil tersebut diketahui besarnya pengaruh langsung dan tidak langsung serta pengaruh Produk, Harga, dan Pelayanan Pengembang sebagai variabel eksogen terhadap Kepuasan Konsumen ( $\left.\mathrm{Y}_{1}\right)$ dan $\mathrm{Y}_{1}$ sebagai variabel endogen terhadap WOM (Word of Mouth).

Sesuai dengan kerangka konsep penelitian dapat dihasilkan 2 fungsi linier yaitu : (1) fungsi model struktur 1 dan (2) fungsi model sub struktur 2. Kedua fungsi yang dihasilkan tersebut secara simultan tergabung menjadi model jalur. Variabel eksogen adalah variabel yang mempengaruhi variabel endogen. Pengaruh antara eksogen dan endogen dijelaskan sebagai berikut :

1. Pada fungsi 1 (sub-struktur 1 ), variabel eksogen $=X_{1} X_{2} X_{3}$ dan variabel endogen $=\mathrm{Y}_{1}$.

Pengaruh langsung terhitung seperti pada standardize regression weight (koefisien). Pada fungsi - $1 \mathrm{X}_{1} \mathrm{X}_{2}$ dan $\mathrm{X}_{3}$ tidak mempunyai penaruh tidak langsung pada $Y_{1}$.total pengaruh masing-masing variabel eksogen terhadap $\mathrm{Y}_{1}$ sama dengan pengaruh langsungnya. Penulisan fungsi atau model -1 dalam bentuk standar adalah :

$\mathrm{Y}_{1}=\mathrm{b}_{1} \mathrm{X}_{1}+\mathrm{b}_{2} \mathrm{X}_{2}+\mathrm{b}_{3} \mathrm{X}_{3}+\mathrm{e} \ldots . .(1)$

$\mathrm{Y}_{1}=0,329+0,134+0,463+0,258$

Berdasarkan model path yang telah dihasilkan diatas selanjutnya dapat di interprestasikan sebagai berikut :

a. Produk $\left(X_{1}\right)$ sebesar 0,329 atinya jika variabel independent lainnya bernilai tetap dan produk $\left(\mathrm{X}_{1}\right)$ mengalami kenaikan 1 angka, maka kepuasan konsumen ( $\mathrm{Y}_{1}$ ) akan mengalami kenaikan sebesar 0,329. Koefisien bernilai positif artinya terjadi hubungan positif antara produk terhadap kepuasan konsumen, dimana semakin naik nilai produk maka akan semakin meningkat pula kepuasan konsumen..

b. Harga $\left(\mathrm{X}_{2}\right)$ sebesar 0,134 atinya jika variabel independent lainnya bernilai tetap dan harga $\left(\mathrm{X}_{2}\right)$ mengalami kenaikan 1 angka, maka kepuasan konsumen ( $\left.\mathrm{Y}_{1}\right)$ akan mengalami kenaikan sebesar 0,134. Koefisien bernilai positif artinya terjadi hubungan positif antara harga terhadap kepuasan konsumen, maka akan semakin meningkat pula kepuasan konsumen..

c. Pelayanan Pengembang $\left(X_{3}\right)$ sebesar 0,463 atinya jika variabel independent lainnya bernilai tetap dan pelayanan pengembang $\left(\mathrm{X}_{3}\right)$ mengalami kenaikan 1 angka, maka kepuasan konsumen ( $\left.\mathrm{Y}_{1}\right)$ akan mengalami kenaikan sebesar 0,463. Koefisien bernilai positif artinya terjadi hubungan positif antara pelayanan pengembang terhadap 
kepuasan konsumen, dimana semakin naik nilai pelayanan pengembang maka akan semakin meningkat pula kepuasan konsumen.

2. Pada fungsi - 2 (sub strukrural 2) variabel endogen $Y_{1}$ dan $Y_{2}$

Maka $\mathrm{Y}_{2}=\mathrm{Y}_{1}+\mathrm{e}$

$$
\mathrm{Y}_{2}=0,880+0,226
$$

Kepuasan konsumen $\left(\mathrm{Y}_{1}\right)$ sebesar 0,880 atinya jika variabel independent lainnya bernilai tetap dan produk ( $\left.\mathrm{X}_{1}\right)$ mengalami kenaikan 1 angka, maka kepuasan konsumen ( $\left.\mathrm{Y}_{1}\right)$ akan mengalami kenaikan sebesar 0,880. Koefisien bernilai positif artinya terjadi hubungan positif antara kepuasan konsumen terhadap WOM (Word of Mouth), dimana semakin naik nilai produk maka akan semakin meningkat pula WOM (Word of Mouth).

\section{PEMBAHASAN}

\section{a. Produk terhadap kepuasan konsumen}

Hasil analisis menyatakan bahwa produk berpengaruh positif dan signifikan terhadap kepuasan konsumen. Hal ini dibuktikan pada nilai $\mathrm{t}$ hitung $>\mathrm{t}$ tabel atau 2,694 $>1,96$ dan angka signifikan 0,009 $<0,05$ hal ini berarti bahwa peningkatan varibel produk akan mendorong peningkatan kepuasan konsumen. Pengertian diatas bermakna bahwa jika produk melalui keragaman produk, kualitas produk, design, ukuran dan garansi mampu mendorong kepuasan konsumen. Dengan keragaman produk yang disajikan atau ditawarkan kepada konsumen menjadi salah satu daya tarik untuk konsumen memilih mana yang menjadi pilihannya dalam memilih atau memiliki perumahan di Villa Ana Residence.

Dengan kualitas produk yang disajikan atau diberikan oleh pihak pengembang kepada konsumen itu merupakan hal yang paling penting bagi konsumen karena semua konsumen sangat melihat kualitas produk yang ditawarkan. Design ukuran dan garansipun tidak kalah menariknya bagi konsumen maka dari itu semua indikator sangat berkaitan erat bagi kepuasan konsumen.

Secara keseluruhan variabel produk terhadap kepuasan konsumen hal ini dapat dilihat dari nilai rata-rata produk (X1) 3,6800 ada rentang dari nilai $(3,4-4,2)$ katagori baik. Presepsi produk terhadap kepuasan konsumen baik.

Kaitannya dengan beberapa penelitian terdahulu membuktikan bahwa produk salah satu variabel yang berpengaruh positif dan signifikan terhadap kepuasan konsumen. Hal ini juga membuktikan bahwa pengertian produk menurut Kotler dan Amstrong (2004:338) adalah segala sesuatu yang ditawarkan ke pasar untuk mendapatkan perhatian, dibeli, dipergunakan dan yang dapat memuaskan keinginan atau kebutuhan konsumen. 


\section{b. Harga terhadap kepuasan konsumen}

Hasil analisis menyatakan bahwa harga tidak berpengaruh positif dan tidak signifikan terhadap kepuasan konsumen. Hal ini dibuktikan pada nilai $t$ hitung $<\mathrm{t}$ tabel 1,247 < 1,96 dengan angka signifikan 0,217 > 0,05 hal ini berarti bahwa peningkatan variabel Harga tidak mendorong peningkatan kepuasan terhadap konsumen. Pengertian diatas bermakna bahwa jika harga melalui indikator harga sesuai dengan kemampuan konsumen, harga sesuai dengan kualitas, program diskont harga, potongan harga khusus dan periode pembayaran itu semua tidak mempengaruhi dan mampu mendorong terhadap kepuasan konsumen.

Secara keseluruhan harga terhadap kepuasan konsumen kalau melihat dari nilai rata-rata harga (X2) adalah 3,6320 ada rentang $(3,4-4,2)$ dikatagorikan baik, presepsi harga terhadap kepuasan konsumen melihat nilai diatas baik, namun dilihat dari nilai t hitung < ttabel maka dinyatakan tidak berpengaruh positif dan signifikan terhadap kepuasan konsumen.

Harga memiliki pengaruh yang tidak signifikan terhadap kepuasan konsumen. Dalam hal ini yang paling mempengaruhi dari indikator harga yaitu harga sesuai dengan kemampuan konsumen karena konsumen dalam hal ini ada beberapa golongan diantaranya golongan menengah kebawah (midle class ) dan menengah keatas (high class). Harga yang ditawarkan kepada konsumen itupun bervariaf tergantung dari type atau klaster perumahan yang ditawarkan dan keempat indikator yaitu harga sesuai dengan kualitas, program diskon harga, potongan harga dan periode pembayaran sudah ditawarkan dan disajikan kepada konsumen sedemikian rupa. Pada kenyataannya meskipun harga tidak memiliki pengaruh yang signifikan terhadap kepuasan konsumen tapi pihak pengembang telah memberikan tawaran yang terbaik dan bersaing bagi konsumen karena berinvestasi dengan membeli rumah akan semakin baik dikemudian hari.

Hubungan dengan penelitian terdahulu dari hasil penelitian secara keseluruhan bahwa harga merupakan salah satu variabel yang berpengaruh positif dan signifikan terhadap kepuasan konsumen namun dalam penelitian ini hasil analisi tersebut bahwa harga tidak berpengaruh positif dan signifikan terhadap kepuasan konsumen karena salah satu alasannya adalah bahwa harga dipengaruhi oleh beberapa faktor baik faktor internal salah satunya adalah bahwa tingkatan konsumen ada beberapa kelas yaitu midle class (kelas menengah ke bawah) dan High class (kelas menengah keatas). Hal inipun ada kaitannya dengan teori menurut para ahli yaitu menurut Machfoedz (2005:136)" Penetapan harga dipengaruhi oleh berbagai faktor, baik faktor internal atau faktor eksternal". Faktor internal meliputi tujuan pemasaran perusahaan strategi bauran pemasaran biaya, dan metode penetapan harga. Faktor eksternal meliputi sifat pasar dan permintaan, persaingan dan elemen lingkungan yang lain. 


\section{c. Pelayanan pengembang terhadap kepuasan konsumen}

Hasil analisis menyatakan bahwa pelayanan pengembang berpengaruh positif dan signifikan terhadap kepuasan konsumen. Hal ini dibuktikan drnagn nilai $t$ hitung $>t$ tabel atau 4,613 > 1,96 dengan akngka signifikan $0,000<0,05$ hal ini berarti bahwa peningkatan variabel pelayanan pengembang akan mendorong peningkatan kepuasan konsumen. Pengertian diatas bermakna bahwa jika pelayanan pengembang melalui kepercayaan atau reliability, daya tanggap atau responsiveness, keyakinan atau Assurance, empaty, dan berwujud atau tangible mampu mendorong kepuasan konsumen.

Secara keseluruhan pelayanan pengembang terhadap kepuasan konsumen rata-rata nilai pelayanan pengembang (X3) adalah 3,5840 ada rentang nilai antara $(3,4-4,2)$ dikategorikan baik. Presepsi pelayanan pengembang terhadap kepuasan konsumen baik.

Pelayanan pengembang memiliki pengaruh yang signifikan terhadap kepuasan konsumen. Indikator-indikator yang terpenting dalam layanan pengembang ini adalah kepercayaan atau reliability. Daya tanggap atau responsiveness, keyakinan atau assurance, empaty dan berwujud atau tangible merupakan hal-hal yang penting yang harus diberikan kepada konsumen dari pihak pengembang karena dengan pelayanan yang baik akan menimbulkan rasa senang dan respon yang sangat luar biasa dari konsumen sehingga menimbulkan rasa puas kepada kosumen dan dengan rasa senang itu mengakibatkan daya tarik bagi konsumen untuk memiliki dan menghuni di perumahan Villa Ana Residence.

Hubungan dengan penelitian terdahulu bahwa secara keseluruhan hasil penelitian terdahulu membuktikan bahwa pelayanan atau kualitas pelayanan berpengaruh positif dan signifikan terhadap kepuasan konsumen. Hal ini dapat dibuktikan dengan teori menurut kotler 5 aspek yang menentukan mutu pelayanan yaitu:

a. Kepercayaan atau reliability, yaitu kemampuan untuk memberikan pelayanan dengan baik dan sesuai apa yang telah dijanjikan dengan tepat.

b. Daya tanggap atau responsiveness yaitu kemampuan melayani yang berfokus pada pelayanan untuk membantu konsumen dan memberikan sevice dengan cepat atau tanggap.

c. Keyakinan atau assurance, yaitu kemampuan untuk memberikan pelayanan dengan mengutamakan aspek kesopanan, pengetahuan dan skill sehingga membuat konsumen merasa percaya dan yakin akan mutu perusahaan yang bersangkutan.

d. Empaty, yakni kemampuan untuk memberikan pelayanan dengan mengedepankan rasa kepedulian dan perhatian pribadi kepada 
konsumen. Hal ini akan membuat konsumen merasa nyaman dan senang bisa berinteraksi dengan institusi tersebut.

e. Berwujud atau tangibles, yaitu kemampuan untuk melayani dengan didukung oleh fasilitas, penampilan, peralatan, personal dan media komunikasi yang baik demi kenyamanan dan kepercayaan konsumen.

\section{d. Kepuasan konsumen terhadap WOM (Word of Mouth)}

Hasil analisis menyatakan bahwa kepuasan konsumen berpengaruh positif dan signifikan terhadap WOM (word of mouth) . Hal ini dibuktikan dengan nilai $\mathrm{t}$ hitung $>\mathrm{t}$ tabel atau 15,818 > 1,96 dan angka signifikan 0,000< 0,05 hal ini berarti bahwa peningkatan variabel kepuasan konsumen akan mendorong peningkatan WOM (word of mouth). Pengertian diatas bermakna bahwa jika kepuasan konsumen melalui indikator-indikator diantaranya: kesesuaian tarif harga, kepuasan dengan harga, perasaan senang, sesuai harapan konsumen, dan pelayanan secara keseluruhan memuaskan mampu mendorong terciptanya WOM (word of mouth).

Secara keseluruhan kepuasan konsumen terhadap WOM (word of mouth) melihat nilai rata_rata kepuasan konsumen (Y1) adalah 3,7413 ada rentang nilai $(3,4-4,2)$ katagori baik. Presepsi kepuasan konsumen terhadap WOM (word of mouth) baik.

Kepuasan konsumen memiliki pengaruh yang signifikan terhadap WOM (Word Of Mouth). Diantara keempat indikator yang dijadikan prioritas yang utama yaitu menceritakan hal yang positif untuk meningkatkan Word of Mouth. Jadi apabila perumahan Villa Ana Residence mampu meningkatkan kepuasan konsumen secara keseluruhan, memberikan kesan yang baik, memberikan informasi yang terpercaya, membuat konsumen senang berada dan menghuni di perumahan Villa Ana residence, maka akan meningkatkan Word of Mouth (WOM) terhadap Villa Ana residence. Hasil penelitian ini sesuai dengan hasil penelitian Hennig Thuran, Gremler dan Gwinner (2002), Prabu dan Ranaweera (2003), Babin, Eun-ju, Griffin, dan yongki (2005) dan Chew Sn Wirts (2002) yang menyatakan bahwa kepuasan konsumen memiliki pengaruh yang signifikan terhadap Word of Mouth.

Semakin tinggi kepuasan pelanggan atau konsumen maka semakin tinggi Word of Mouth yang positif dapat diterima. Melihat nilai estimate yang bernilai positif dapat diartikan bahwa pengaruh kepuasan konsumen terhadap Word of Mouth yang positif adalah positif, artinya semakin tinggi kepuasan pelanggan maka semakin tinggi Word of Mouth yang positif tersebut.

Hubungan dengan penelitian terdahulu membuktikan bahwa kepuasan konsumen berpengaruh positif dan signifikan terhadap WOM (word of mouth). Hal ini juga didukung oleh teori Babin et al (2005) menyatakan bahwa kepuasan konsumen atau pelanggan berpengaruh positif terhadap minat WOM. 
Kepuasan konsumen atau pelanggan dapat mempengaruhi hasil kinerja, termasuk loyalitas dan komunikasi WOM atau minat mereferensikan. Oleh sebab itu, kepuasan konsumen atau pelanggan mendorong terciptanya komunikasi WOM (Thurau et al, 2003).

Menurut Tse dan Wilton dalam Jiptono (2007:65), kepuasan atau ketidak puasan konsumen adalah respon konsumen terhadap evaluasi ketidak sesuaian yang dirasakan antara harapan sebelumnya (norma kinerja lainnya) dan kinerja actual produk yang dirasakan setelah pemakaiannya. Terciptanya kepuasan konsumen akan memberi manfaat, diantaranya membentuk rekomendasi dari mulut ke mulut (word of mouth). Konsumen yang merasa puas bahkan sangat puas (delihted customer) cenderung akan menjadi duta bagi perusahaan (Apostles of a firm), konsumen hanya kan membeli dari satu pemasok dan akan menyebarkan berita yang baik tentang produk dan perusahaan. Selain itu Lovelock dan Wright. ${ }^{14}$ bahwa konsumen yang sangat puas akan menyebarkan cerita positif dari mulut ke mulut dan bahkan akan menjadi iklan berjalan dan akan berbicara bagi suatu perusahaan.

\section{Kesimpulan Dan Saran}

\section{a. Kesimpulan}

Berdasarkan hasil analisis dalam pembahasan yang dikemukakan sebelumnya, maka penelitan ini dapat disimpulkan sebagai berikut :

1. Produk berpengaruh positif dan signifikan terhadap kepuasan konsumen. Jika variabel produk melalui keragaman produk, kualitas produk, design, Ukuran dan garansi mampu mendorong peningkatan kepuasan konsumen.

2. Harga tidak berpengaruh positif dan signifikan terhadap kepuasan konsumen, Jika variabel harga melalui harga sesuai dengan kemampuan konsumen hal ini benar adanya karena tingkatan konsumen terdiri dari beberapa kelas yaitu kelas menengah kebawah (midle class) dan ada kelas menengah keatas (high class), karena melalui harga sesuai dgn kualitas, program diskon harga, potongan harga khusus, periode pembayaran tidak mampu mendorong peningkatan kepuasan konsumen.

3. Pelayanan pengembang berpengaruh positif dan signifikan terhadap kepuasan konsumen. Jika variabel pelayanan pengembang melalui kepercayaan atau reliability, daya tanggap atau responsiveness, keyakinan atau assurance, Empaty, berwujud atau tangible mampu mendorong peningkatan kepuasan konsumen.

4. Kepuasan konsumen berpengaruh positif dan signifikan terhadap WOM (word of mouth). jika variabel kepuasan konsumen melalui tarif harga,

${ }^{14}$ Christopher Lovelock and Jochen Wirtz, Service..., 105 
kepuasan dengan produk, perasaan senang, sesuai harapan konsumen dan pelayanan secara keseluruhan memuaskan mampu mendorong peningkatan terhadap WOM (word of mouth).

\section{b. Saran}

Beberapa Agenda dan saran penelitian mendatang yang masih mungkin dikembangkan lebih lanjut :

1. Penelitian ini masih memungkinkan untuk dikembangkan dalam menguji ulang model penelitian dengan menambah variabel baru seperti minat beli pada produk.

2. Penelitian mendatang diharapkan mampu mengembangkan konseptual dan permodalan kajian ini pada objek - objek kajian penelitian yang lebih luas dengan tetap pada skema loyalitas pelanggan dibidang atau industry yang lain dengan demikian dapat diperoleh perbandingan mengenai hasilhasil dari usaha peningkatan layanan diberbagai industri yang ditinjau dari berbagai variabel.

3. Penelitian berikutnya dapat mengkaji ulang model penelitian ini dengan menambah variabel-variabel baru, citra perusahaan berpengaruh terhadap loyalitas pelanggan dan kualitas pelayanan terhadap kepuasan pelanggan.

4. Apabila perusahaan suatu saat akan mengembangkan perusahaannya dan membuka projek baru disarankan salah satunya memperhatikan tempat atau lokasi sebagai objek atau pengembangan Hunian yang salah satunya juga sebagai daya tarik bagi konsumen untuk memiliki hunian tersebut. 


\section{DAFTAR PUSTAKA}

Assauri Sofjan. 2003. Manajemen Pemasaran ed. 1-12. Rajawali pers. Jakarta.

Aaker David A. 2013. Edisi 8. Strategic market Management 8 th ed. Penerjemah david Wijaya, Herwita titi sekartaji, Hersan kurnia, Salemba. Jakarta Selatan.

Chaniotakis, E and Cymperapoulus C. 2009. Service Quality Effect on Satisfaction and Word of Mouth in the Health Care Industry. Managing Service Quality, Vol. 19, No 2, PP The Rotation 229 - 242.

Chen, Cherg-Non. 2007. Among social Capital Entrepreneurial orientation, organizational resources and entrepreneurial performance for new venturees, contemporary management research. Nasional cheng kung university.

Daryanto. 2011. Manajemen Pemasaran. Cet 1. Satu Nusa. Bandung.

Djati, S. Pantja dan Didit Hermawan. 2004. Pengaruh Kesan Kualitas, layanan, Harga dan kepuasan Mahasiswa PTS terhadap Mereferensikan Kampusnya. Jurnal widya manajemen dan akuntansi, Vol. 4, No. 2, Agustus, 190 - 204.

Engel, James F. Roger D. Blackwell and Paul W. Miniard. 1993. Consumer Behavior 6 th edition. New York. Dryden Press

Flintoff, John-Paul. 2002. When The Buzz Is Not Quite What It Seems. Financial Times. London.

Ferdinand. Augustly. 2005. Structual Equation Modeling dalam Penelitian Managemen. Badan penerbit Universitas Dipenogoro. Semarang.

Ghozali, Imam . 2004. Aplikasi analisis Multivariate dengan program SPSS Edisi

II. BPFE Universitas Diponogoro, Semarang.

Ghozali, Imam. 2008. Persamaan Struktural, Konsep, Aplikasi dengan Program Amos Ver 5.0. Semarang. GP UNDIP

Harison, L and Walker. 2001. The Measurement of Word of Mouth Communication and an Investigation of Service quality and Customer

Commitment as potential Antecedents. Journal of service research. Vol 4.

Hardianto, Refli.2013. “Analisis Pengaruh Bauran Pemasaran Keputusan Pembelian helm Motor merek GM Di Kota Terhadap Pekanbaru". Hoskins, Jim. 2007. Word of Mouth Research : Principals and Application.

The journal Advertising Research. ARF

Huges, Mark. 2007. Buzzmarketing. Jakarta. PT Elex Media Komputindo.

Hermawan Kertajaya. 2006. Hermawan Kertajaya seri 9, Elemen Marketing on Service. Markplus Vea. 
Irawan, Hadi (2003), “Indonesia Customer Satisfaction : Membedah Strategi". Kepuasan Pelanggan Merek Pemenang ICSA. Jakarta. PT. Elex Media Komputindo.

Ichbal Hilman, Muhammad Noer. 2013. "Analisis Pengaruh Word Of Mouth, marketing Mix (Produk, harga, promosi, dan Saluran Distribusi), dan Citra Merek Terhadap Keputusan pembelian Mobil Suzuki Swift. Universitas Islam Negeri Syarif Hidayatullah,. Jakarta.

Juandi, Hendy Irawan. 2004. Kepuasan Layanan Jasa. Erlangga. Jakarta.

Jonathan Sarwono.2012. metode Riset Skripsi Pendekatan kuantitatif (menggunakan prosedur SPSS). Jakarta, PT. Elex Media komputindo.

Kotler P. dan Keller, K. L. 2008. Manajemen Pemasaran. Edisi kedua belas jilid

2 , edisi bahasa inggris, person education, inc. Upper saddler river. New Jersey. 07458. Edisi Bahasa Indonesia pada PT. INDEKS.

Kotler P. dan Keller, K. L. 2008. Manajemen Pemasaran. Edisi ketiga belas jilid 1. Edisi bahasa inggris, Person education, inc. original ISBN : 978-0-13 600998-6. Edisi bahasa Indonesia pada penerbit Erlangga.

Kuncara, Mudrajad. 2009. Metode Riset untuk Bisnis \& Ekonomi. Jakarta. Penerbit Erlangga.

Keller. Ed. 2007. Unleshing the power of Word of Mouth Creating Brand Advocacy to drive Growth the Journal of Advertising Research.ARF.

Luo, Xiening \& Hamburg, Christian. 2007. Neglected outcomes of cutomer satisfaction. Journal of marketing. Santa Barbara.

Lovelock,Christopher and Jochen Wirtz, 2008. Service Marketing people technology strategy. Sixty Edition, Singapore, Prentree Hall

Mulyadi. 2007. "Efektifitas Word of Mouth". Marketing 03/VII/maret 5354.Nita, A. 2011. Pengaruh kualitas produk dan kualitas layanan terhadap kepuasan dan loyalitas pelanggan. (Studi pada pelanggan warung Mina Peguyangan). Tesis, Progam magister Manajemen Universitas Udayana Denpasar.

Nugroho, Agung Buwono. "Strategi Jitu Memilih Metode Statistik Penelitian Dengan SPSS", CV. Andi Offset, Yogyakarta, 2005.

Pujiana, Ika Lestari. 2012. “ Pengaruh Word Of Mouth Comunications Terhadap Proses Pengambilan Keputusan Pembelian (Survei Pada Pelanggan Klinik Kecantikan Auraku Skin Solutions Ruko Perumahan Taman Mutiara M-8. Cimahi).

Sekaran, U. 2006. Metode Penelitian Kuantitatif Kualitatif dan R\&D. CV Alfabeta. Bandung.

Setyawati, Indah. 2009. Analisis Pengaruh Kualitas Layanan dan Kepuasan Pasien terhadap Word of Mouth ( Studi pada Pasien Rawat Jalan RS. Bari Wira Tamtama Semarang). Tesis, Program Studi Magister Manajemen Universitas Diponogoro, Semarang. 
Determinan Yang Mempemgaruhi Kepuasan Hunian

Sugiyono. 2008. Metode Penelitian Bisnis. Bandung. Penerbit Alfabeta.

Suyanto M. 2007. Marketing Strategy Top Brand Indonesia. ANDI. Jogyakarta. 